\title{
Essential role of calcium in the regulation of MAP kinase phosphatase-1 expression
}

\author{
Jean-Claude Scimeca, Marc J Servant, Joseph-Omer Dyer and Sylvain Meloche \\ Centre de Recherche, Hôtel-Dieu de Montréal and Department of Pharmacology, University of Montreal, Montreal, Quebec, \\ Canada $\mathrm{H} 2 \mathrm{~W} 1 \mathrm{~T} 8$
}

\begin{abstract}
Mitogen-activated protein (MAP) kinase phosphatase-1 (MKP-1) is a dual-specificity protein phosphatase encoded by an immediate-early gene responsive to growth factors and stress. The MKP-1 protein selectively inactivates MAP kinases in vitro by dephosphorylation of the regulatory $T h r$ and $T y r$ residues. Little is known on the mechanisms that regulate $M K P-1$ gene expression. Here, we demonstrate that $\mathrm{Ca}^{2+}$ is both necessary and sufficient for the induction of $M K P-1$ gene expression. Treatment of Rat1 fibroblasts with the $\mathrm{Ca}^{2+}$ chelating agent BAPTA completely suppressed serum-induced MKP-1 expression in a dose- and timedependent manner. The inhibitory effect of BAPTA was observed at the level of the protein and the mRNA. Importantly, $\mathrm{Ca}^{2+}$ chelation blocked the induction of MKP-1 expression in response to all stimuli tested and in different cell types. Increasing the intracellular concentration of $\mathrm{Ca}^{2+}$ with the ionophore A23187 was sufficient to induce MKP-1 mRNA and protein expression in rat fibroblasts. We also provide evidence that activation of MAP kinases is not an absolute requirement for induction of the $M K P-1$ gene. Exposure of rat fibroblasts to A23187 induced MKP-1 expression without activating the JNK and p38 MAP kinase pathways. Also, inhibition of the ERK pathway with the selective MEK inhibitor PD98059 did not interfere with serumstimulated $M K P-1$ mRNA expression. These results will help define the regulatory mechanisms that govern $M K P$ 1 gene transcription in target cells.
\end{abstract}

Keywords: phosphatase; MAP kinase; gene expression; calcium

\section{Introduction}

Mitogen-activated protein (MAP) kinases are a family of proline-directed serine/threonine kinases which play a key role in transducing signals from a wide range of extracellular stimuli into intracellular responses. Three distinct subfamilies of MAP kinases are currently known in vertebrates: the extracellular signal-regulated kinases (ERKs), the stress-activated protein (SAP)/Jun $\mathrm{N}$-terminal kinases (JNKs), and p38 (reviewed in (Davis, 1994; Cano and Mahadevan, 1995; Cobb and Goldsmith, 1995)). The ERK isoforms ERK1/ERK2 are activated in response to mitogenic and differentiation factors (Cobb et al., 1991; L'Allemain, 1994), whereas JNKs and p38 respond mainly to environ-

Correspondence: S Meloche

Received 23 December 1996; revised 18 April 1997; accepted 24 April 1997 mental stress and proinflammatory cytokines (Kyriakis et al., 1994; Han et al., 1994; Rouse et al., 1994; Raingeaud et al., 1995; Force et al., 1996). The activation of MAP kinases is mediated by a family of dual-specificity enzymes, called MAP kinase kinases, which phosphorylate the proteins on both threonine and tyrosine residues within the sequence T-X-Y (Cobb and Goldsmith, 1995; Waskiewicz and Cooper, 1995). On the other hand, much less is known on the mechanisms leading to inactivation of MAP kinases.

Recently, a novel family of dual-specificity protein phosphatases capable of dephosphorylating the regulatory threonine and tyrosine residues of MAP kinases has been described (reviewed in Keyse, 1995). All these enzymes bear the characteristic active-site motif of protein tyrosine phosphatases (PTPs) and display sequence homology to the vaccinia virus VH1 phosphatase (Guan et al., 1991). The first mammalian gene of this family to be discovered was mouse 3 CH134 (also known as erp) and its human homologue CL100 (also known as $h V H-1$ ) which was isolated as an immediate-early gene inducible by growth factors and stress (Charles et al., 1992; Keyse and Emslie, 1992; Noguchi et al., 1993; Zheng and Guan, 1993). Recombinant 3CH134/CL100 purified from bacteria preferentially dephosphorylates the phosphothreonine and phosphotyrosine residues of MAP kinases in vitro resulting in their inactivation (Charles et al., 1993; Alessi et al., 1993; Zheng and Guan, 1993). Overexpression of 3CH134 in COS cells leads to dephosphorylation and inactivation of ERK1/ ERK2; and catalytically-inactive 3CH134 physically associates with the phosphorylated form of ERK1/ ERK2 in intact cells (Sun et al., 1993). On the basis of these results, the 3CH134/CL100 phosphatase was renamed MAP kinase phosphatase-1 (MKP-1). The expression of MKP-1 was further shown to inhibit ERK-dependent reporter gene activity (Sun et al., 1994b; Brondello et al., 1995), to block cell cycle progression and entry into $\mathrm{S}$ phase of fibroblast cells (Noguchi et al., 1993; Sun et al., 1994b; Brondello et al., 1995) and to prevent $\mathrm{PC} 12$ cell differentiation (Fukuda et al., 1995). All these observations suggest that MKP-1 might be a physiological MAP kinase phosphatase, but its relative contribution to the inactivation of MAP kinases in specific cellular processes in vivo remains to be established.

Other members of the VH1 family of dual-specificity protein phosphatases include VHR (Ishibashi et al., 1992), PAC-1 (Rohan et al., 1993), MKP-2/hVH-2/ TYP-1 (Guan and Butch, 1995; Misra-Press et al., 1995; King et al., 1995), B23/hVH-3 (Ishibashi et al., 1994; Kwak et al., 1995), hVH-5 (Martell et al., 1995) and rVH-6/MKP-3 (Mourey et al., 1996; Muda et al., 
1996). These gene products have unique but overlapping tissue distribution patterns. Like MKP-1, all the enzymes exhibit activity towards phosphorylated ERK1/ERK2 in vitro. Moreover, in vivo expression of PAC-1, MKP-2, and MKP-3 interferes with growth factor-dependent phosphorylation and enzymatic activation of ERK1/ERK2 (Ward et al., 1994; King et al., 1995; Muda et al., 1996; Chu et al., 1996). Interestingly, recent results obtained in transient transfection experiments suggest that individual MAP kinase phosphatases may have distinct specificities for the ERK, JNK and p38 MAP kinases (Chu et al., 1996).

Little is known on the mechanisms by which growth factors and stress activate transcription of the gene encoding MKP-1. The induction of $M K P-1$ mRNA expression has been observed in several cell types in response to stimuli as diverse as growth and differentiation factors, cAMP-elevating agents, phorbol esters, heat shock, oxidative stress, and genotoxic agents (Charles et al., 1992; Keyse and Emslie, 1992; Noguchi et al., 1993; Duff et al., 1993; Liu et al., 1995). The aim of this study was to characterize the signalling pathways involved in the regulation of MKP-1 expression. We demonstrate that calcium is both necessary and sufficient for $M K P-1$ gene expression in fibroblast and smooth muscle cells. Moreover, we provide strong evidence that the three MAP kinases, ERKs, JNKs and p38, are not obligatory components of the pathways leading to transcription of the $M K P-1$ gene in fibroblast cells.

\section{Results}

Calcium is necessary for induction of MKP-1 gene expression

To determine whether MKP-1 expression is controlled by reversible protein phosphorylation, we first examined the effect of two non selective protein kinase inhibitors, 2-aminopurine and K-252a (Mahadevan et al., 1990; Kase et al., 1987), on serum-induced expression of MKP-1. Growth-arrested Rat1 fibroblasts were pre-treated for $30 \mathrm{~min}$ with increasing concentrations of 2-aminopurine or $\mathrm{K}-252 \mathrm{a}$ and then stimulated for 90 min with $10 \%$ calf serum. Cell lysates were prepared and the expression of MKP-1 was analysed by immunoblotting using a specific antibody. Both inhibitors significantly reduced MKP-1 protein expression in a dose-dependent manner (Figure 1). K$252 \mathrm{a}$ was more potent than 2-aminopurine with a maximal inhibitory effect observed at $30 \mathrm{nM}$. In a complementary experiment, we also found that phloretin, an uncoupler and inhibitor of mitochondrial oxidative phosphorylation which depletes cellular stores of ATP (De Jonge et al., 1983), completely abolished the serum-dependent expression of MKP-1 in Rat1 cells (data not shown). These results strongly implicate the action of protein kinase(s) in the regulation of MKP-1 expression.

To gain insights into the nature of the protein kinase(s) involved, we evaluated the effect of selective inhibitors of protein kinase $\mathrm{C}(\mathrm{PKC})$ isoforms, tyrosine kinase inhibitors and a membrane-permeable $\mathrm{Ca}^{2+}$ chelating agent on serum-induced expression of MKP-1. CGP41251 is a compound which inhibits
$\mathrm{Ca}^{2+}$-dependent and independent isoforms of PKC (Meyer et al., 1989; Marte et al., 1994), while Go6976 is more selective for the classical $\mathrm{Ca}^{2+}$-dependent PKC isoforms (Martiny-Baron et al., 1993). As shown in Figure 2a, the two PKC inhibitors, and the biologically inactive analog CGP42700, had no effect on the phosphatase expression level. Similarly, genistein and herbimycin A, two broad spectrum tyrosine kinase inhibitors (Akiyama et al., 1987; Uehara et al., 1989), did not modify the effect of serum on MKP-1 expression (Figure 2b). In contrast, treatment of Rat1 cells with the $\mathrm{Ca}^{2+}$ chelating agent BAPTA resulted in

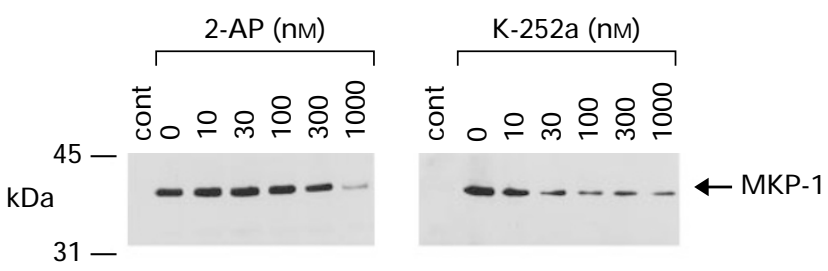

Figure 1 Inhibition of serum-induced MKP-1 expression by non selective protein kinase inhibitors. Quiescent Rat1 fibroblasts were pre-treated for $30 \mathrm{~min}$ with the indicated concentrations of 2aminopurine (2-AP) or K-252a. The cells were then stimulated or not (cont) with $10 \%$ calf serum for $90 \mathrm{~min}$. Equal amounts of lysate proteins were resolved by SDS-gel electrophoresis on $10 \%$ acrylamide gel and transferred to nitrocellulose membrane. The membrane was probed with anti-MKP-1 antibody and the proteins visualized by chemiluminescence detection. The position of MKP-1 is indicated by an arrow
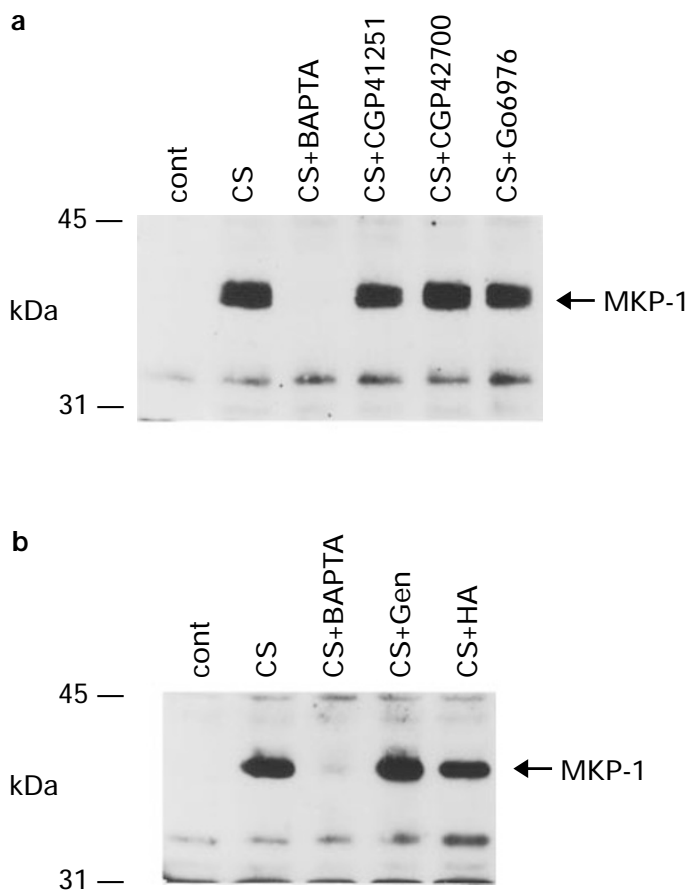

Figure 2 Effect of signalling inhibitors on serum-induced MKP-1 expression in Ratl fibroblasts. Quiescent Ratl fibroblasts were pre-treated for $30 \mathrm{~min}$ with the indicated signalling inhibitors, with the exception of herbimycin A which was present during 20 h. The cells were then stimulated or not (cont) with $10 \%$ calf serum (CS) for $90 \mathrm{~min}$. The expression of MKP-1 protein was analysed by immunoblotting as described in Figure 1. The concentrations of drug inhibitors were: $10 \mu \mathrm{M}$ BAPTA, $10 \mu \mathrm{M}$ CGP41251, $10 \mu \mathrm{M}$ CGP42700, $10 \mu \mathrm{M}$ Go6976, $30 \mu \mathrm{M}$ genistein (Gen) and $0.5 \mu \mathrm{M}$ herbimycin A (HA) 
a complete inhibition of the serum-dependent expression of MKP-1.

These results prompted us to investigate the effect of BAPTA in more detail. Pharmacological studies revealed that BAPTA inhibits MKP-1 expression in a dose-dependent manner with a half-maximal inhibition observed at a concentration of approximately $1 \mu \mathrm{M}$ (Figure 3a). A complete inhibition was observed at $10 \mu \mathrm{M}$ BAPTA. Time-course experiments indicated that addition of BAPTA 60 or $30 \mathrm{~min}$ before serum induced a total inhibition of MKP-1 expression (Figure 3b). When the chelating agent was added together with serum, only a partial inhibition was observed. The inhibitory effect was further reduced when BAPTA was added $30 \mathrm{~min}$ after serum stimulation, and completely disappeared at $60 \mathrm{~min}$. BAPTA also reduced the rate of protein synthesis at this concentration, which may partly account for the effect seen on MKP-1 protein levels (data not shown). In order to determine if the involvement of $\mathrm{Ca}^{2+}$ was specific to the stimulus and/or the cellular context, we examined the effect of BAPTA on two different cell types, Rat1 fibroblasts and rat aortic smooth muscle cells (SMC), treated with various extracellular stimuli. As shown in Figure 4a, MKP-1 protein expression was strongly induced by serum in Rat1 fibroblasts, but also in response to epidermal growth factor, thrombin, phorbol esters, and heat shock. Preincubation of the cells with BAPTA completely abolished MKP-1 expression, whatever the stimulus used. The same experiment was performed in rat aortic SMC using the same stimuli, except for thrombin which was substituted by angiotensin II. As observed for Rat1 cells, MKP-1 expression was induced by all treatments and the response was blocked by BAPTA (Figure $4 b$ ).

a

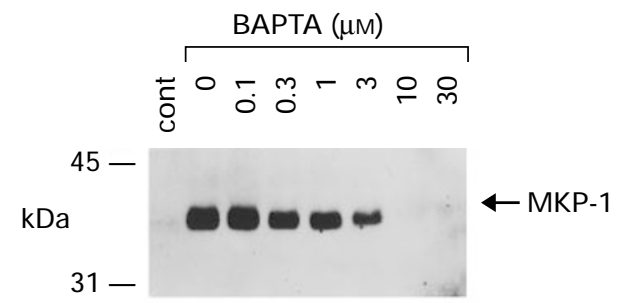

b

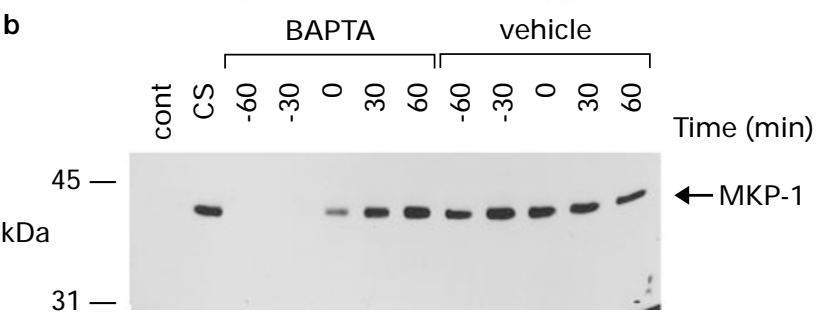

Figure 3 The inhibition of MKP-1 expression by BAPTA is dose- and time-dependent. (a) Quiescent Ratl fibroblasts were pre-treated for $30 \mathrm{~min}$ with different concentrations of BAPTA prior to stimulation with medium (cont) or $10 \%$ calf serum for 90 min. (b) BAPTA $(10 \mu \mathrm{M})$ or vehicle was added at various times before and after the addition of $10 \%$ calf serum to quiescent Rat 1 cells. Time 0 corresponds to the beginning of the $90 \mathrm{~min}$ incubation period with serum. The cells were treated with medium (cont) or $10 \%$ calf serum (CS) for $90 \mathrm{~min}$ as control. The expression of MKP-1 protein was analysed by immunoblotting as described in Figure 1
Since MKP-1 is encoded by an immediate-early gene, it was of interest to determine if the effect of BAPTA is exerted at the transcriptional level. Rat1 fibroblasts were pretreated in the absence or presence of BAPTA before serum stimulation and the level of $M K P-1$ mRNA was analysed by Northern blotting. As expected, serum rapidly and strongly increased the expression of $M K P-1$ mRNA, which reached a maximal level at $30 \mathrm{~min}$ and declined thereafter (Figure 5). In the presence of BAPTA, the induction of $M K P-1$ mRNA expression was almost completely abolished.

\section{Increased calcium concentration is sufficient to induce MKP-1 gene expression}

Together, the preceding results indicated that $\mathrm{Ca}^{2+}$ is required for MKP-1 gene expression. We then wanted to determine if an increase in the intracellular concentration of $\mathrm{Ca}^{2+}$ alone was sufficient to activate the $M K P-1$ gene. Ratl fibroblasts were treated with the $\mathrm{Ca}^{2+}$ ionophore A23187 and the level of MKP-1 expression was monitored as above. As shown in Figure 6a, addition of A23187 increased the expression of MKP-1 protein in a dose-dependent manner with a maximal effect observed at $3 \mu \mathrm{M}$. Time-course experiments revealed that A23187-induced MKP-1 expression reaches a maximum at approximately $2 \mathrm{~h}$ and slowly declines thereafter (Figure 6b). The effect of A23187 was most likely exerted at the level of gene transcription since the ionophore induced a strong and transient accumulation of $M K P-1$ mRNA (eightfold stimulation over basal level) in these cells (Figure 6c). It is interesting to note that the kinetics of MKP-1 induction is slightly slower and the extent of MKP-1 expression is lower in cells treated with A23187 as

a
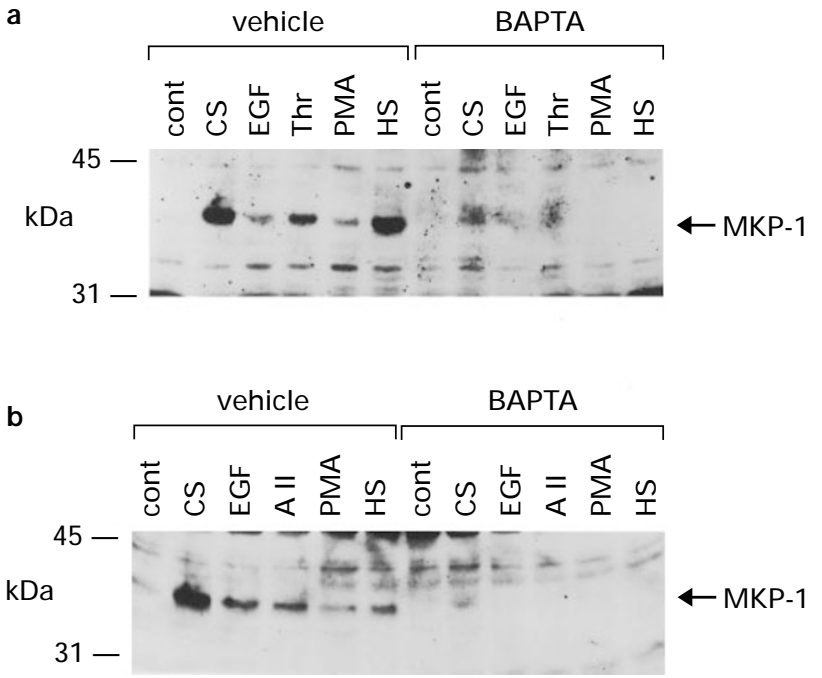

Figure 4 Effect of BAPTA on the induction of MKP-1 expression by various stimuli. Quiescent Ratl cells (a) or rat aortic SMC (b) were pre-treated for $30 \mathrm{~min}$ in the absence (vehicle) or presence of $10 \mu \mathrm{M}$ BAPTA. The cells were then exposed to the following stimuli: medium (cont), $10 \%$ calf serum (CS) for $90 \mathrm{~min}, 100 \mathrm{ng} / \mathrm{ml}$ epidermal growth factor (EGF) for 90 min, $3 \mathrm{U} / \mathrm{ml}$ thrombin (Thr) for $90 \mathrm{~min}, 100 \mathrm{nM}$ PMA for $90 \mathrm{~min}$, $100 \mathrm{~nm}$ angiotensin II (AII) for $90 \mathrm{~min}$ and heat shock at $42^{\circ} \mathrm{C}$ for $30 \mathrm{~min}$ followed by $60 \mathrm{~min}$ at $37^{\circ} \mathrm{C}$ (HS). The expression of MKP-1 protein was analysed by immunoblotting as described in Figure 1 

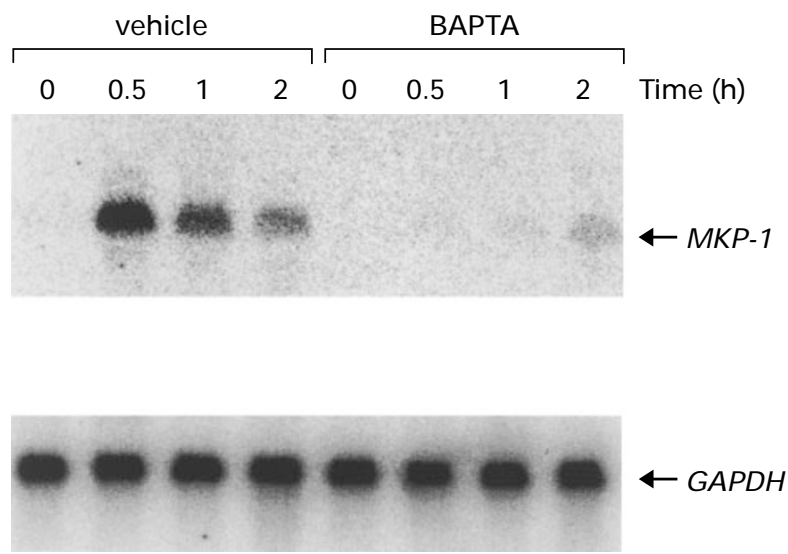

Figure 5 Inhibition of $M K P-1$ mRNA expression by BAPTA in Rat1 fibroblasts. Quiescent Rat1 cells were pre-treated for $30 \mathrm{~min}$ with vehicle or with $10 \mu \mathrm{M}$ BAPTA. The cells were then stimulated for the indicated times with $10 \%$ calf serum. Total RNA was extracted from the cells and analysed by Northern hybridization using a ${ }^{32} \mathrm{P}$-labeled $M K P-1$ probe. The results were normalized by rehybridization of the blot with a $G A P D H$ probe. The extent of hybridization was visualized by phosphorimaging analysis

a
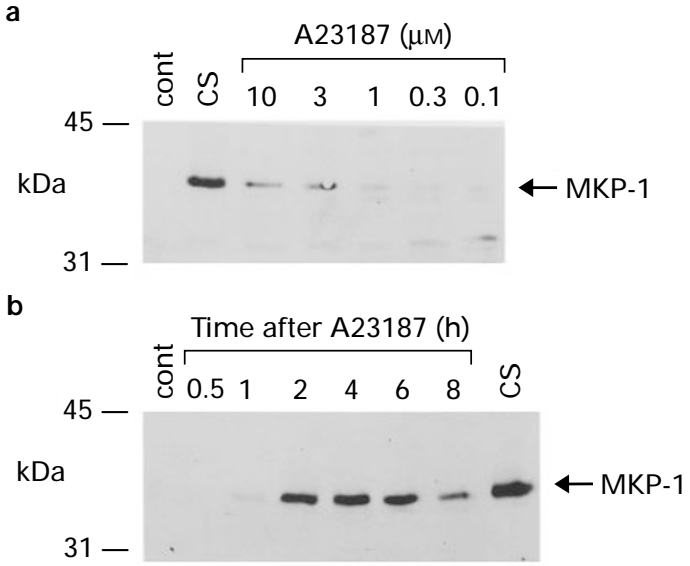

C
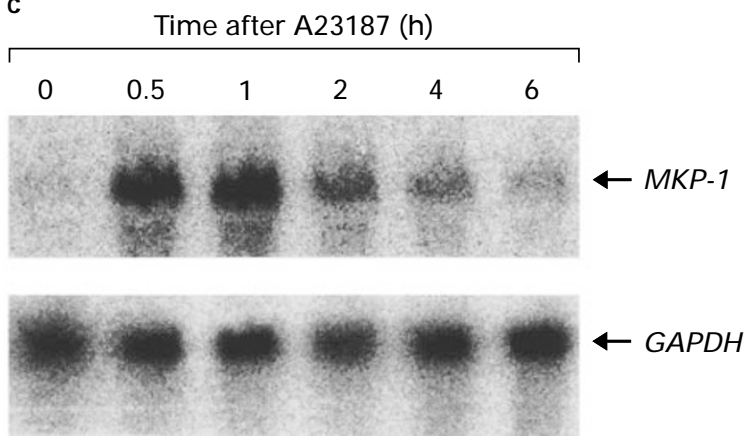

Figure 6 The $\mathrm{Ca}^{2+}$ ionophore A23187 induces $M K P-1$ gene expression in Ratl fibroblasts. Quiescent Ratl fibroblasts were treated with different concentrations of A23187 for $4 \mathrm{~h}$ (a) or with $3 \mu \mathrm{M} \mathrm{A} 23187$ for different period of times (b). The expression of MKP-1 protein was analysed by immunoblotting as described in Figure 1. The cells were stimulated with medium (cont) or with $10 \%$ calf serum (CS) for $90 \mathrm{~min}$ as control. (c) Quiescent Rat1 cells were stimulated with $3 \mu \mathrm{M}$ A23187 for the indicated times. Total RNA was extracted from the cells and analysed by Northern hybridization using a ${ }^{32} \mathrm{P}$-labeled $M K P-1$ probe. Results were normalized by rehybridization of the membrane with a $G A P D H$ probe compared to serum. This suggests that additional signalling pathways might be required for full transcriptional activation of the $M K P-1$ gene.

Induction of MKP-1 gene expression in the absence of MAP kinases activation

We also performed a series of experiments to investigate if MAP kinases, which are putative substrates of the phosphatase, are required for the induction of MKP-1 expression in response to extracellular signals. Indeed, it has been recently proposed that activation of the JNK pathway induces $M K P-1$ gene transcription in NIH3T3 cells (Bokemeyer et al., 1996). We first measured the enzymatic activity of JNK2, ERK1, and p38 in Rat1 cells following stimulation with A23187. $\mathrm{Ca}^{2+}$ influx caused a strong activation of ERK1, which reached a maximum at approximately $15 \mathrm{~min}$ (eightfold stimulation) and remained elevated for at least $2 \mathrm{~h}$ (Figure $7 \mathrm{~b}$ ). In contrast, addition of A23187 did not activate JNK2
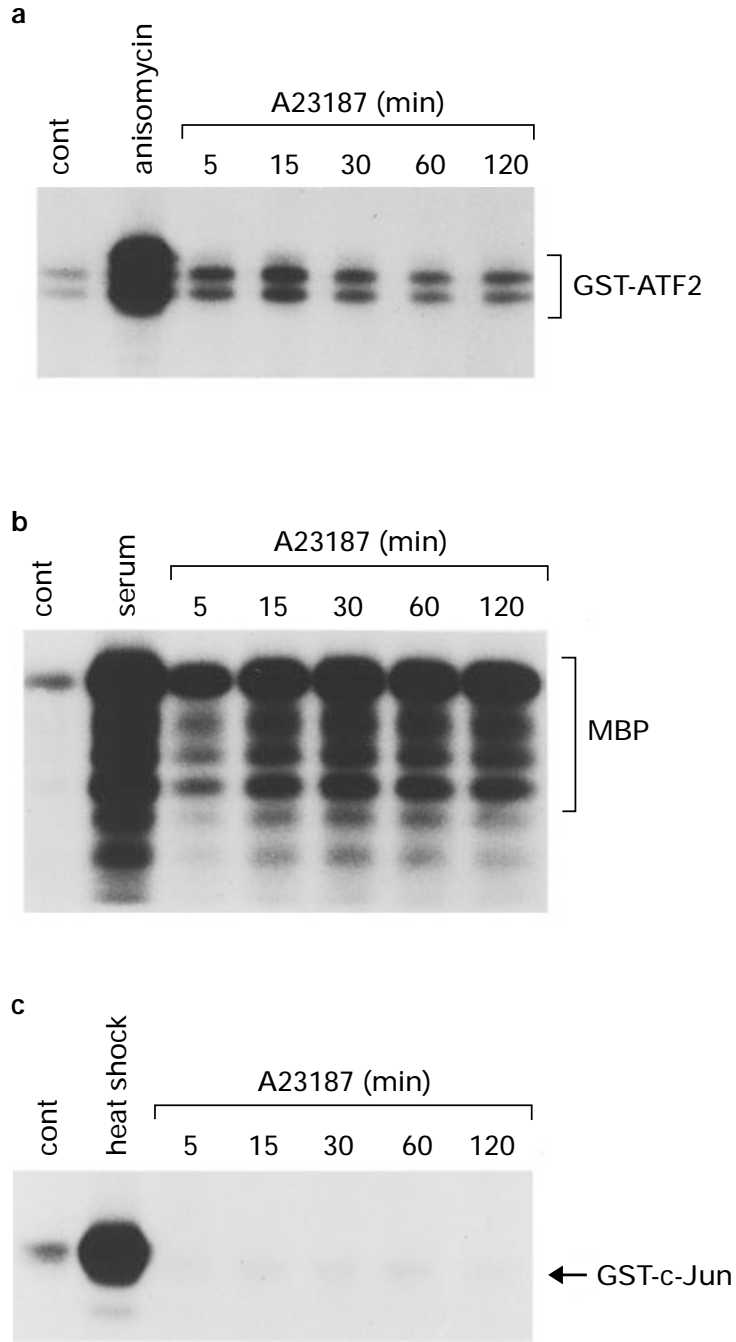

Figure 7 Effect of A23187 on JNK, ERK and p38 MAP kinase pathways in Ratl fibroblasts. Quiescent Ratl cells were stimulated with $3 \mu \mathrm{M} \mathrm{A} 23187$ for the indicated period of times. Cell lysates were prepared and p38 (upper panel), ERK1 (middle panel) or JNK2 (lower panel) were immunoprecipitated using specific antibodies preadsorbed to protein A-Sepharose beads. The phosphotransferase activity of each MAP kinase was assayed directly using GST-ATF2 (p38), MBP (ERK1), or GST-c-Jun (JNK2) as substrate (see Materials and methods) 
and only had a weak (twofold) and transient stimulatory effect on p38 activity (Figure 7c and 7a). Exposure of the cells to heat shock or anisomycin confirmed that JNK2 and p38 are fully active. We next used a pharmacological approach to address the role of the ERK pathway in the induction of $M K P-1$ gene expression. PD98059 is a synthetic drug inhibitor which selectively inhibits the activity of ERK1/ERK2 by
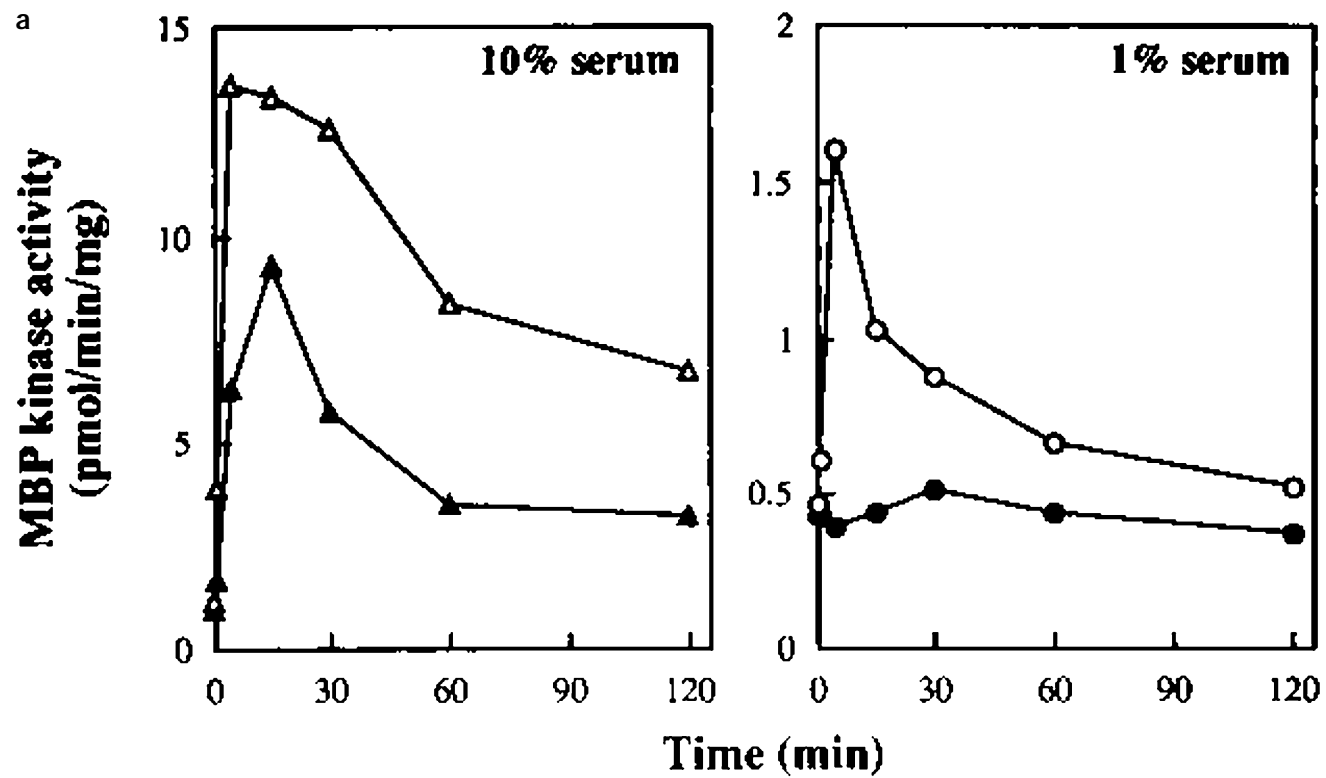

b

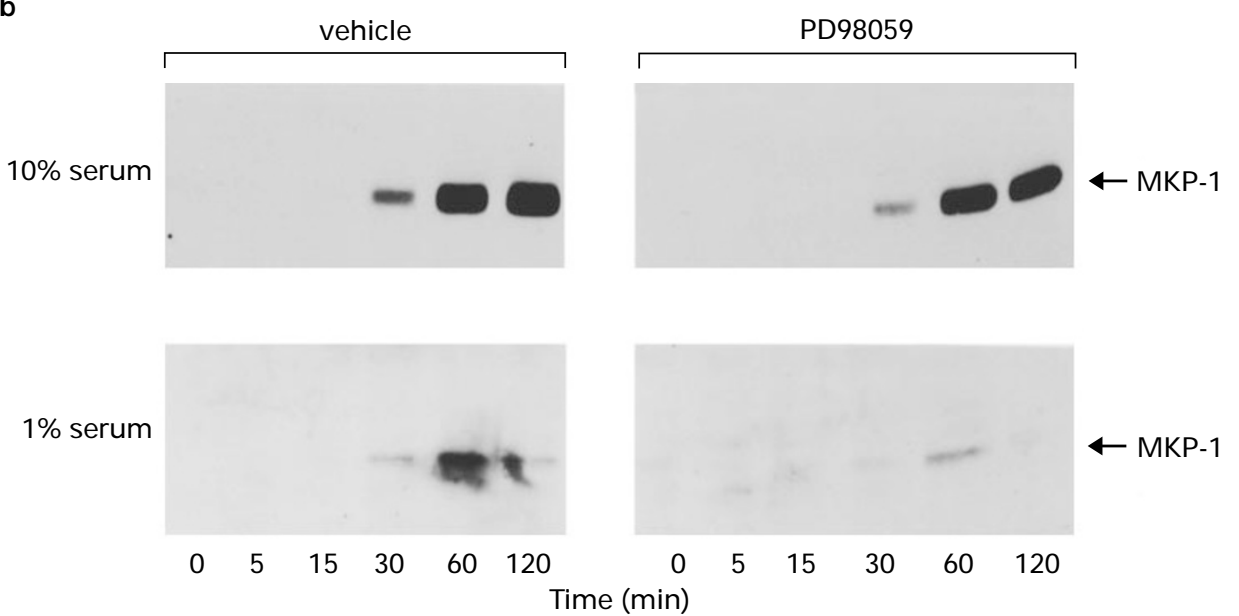

c
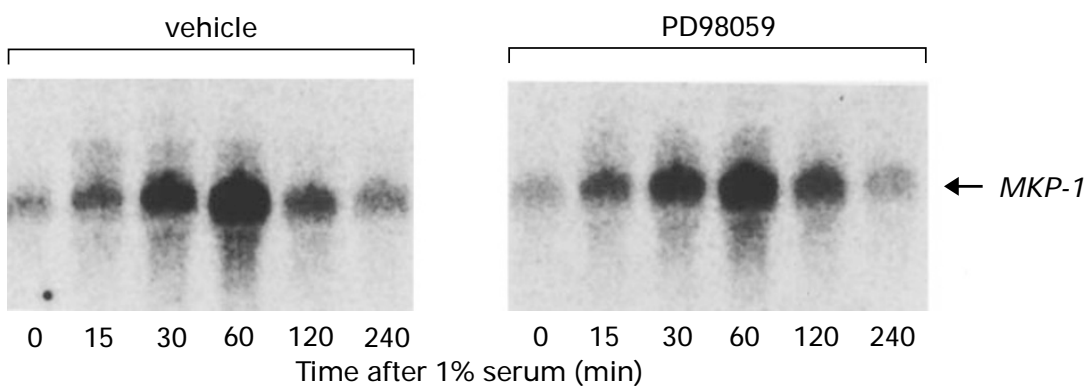

Figure 8 Effect of the MEK inhibitor PD98059 on MKP-1 gene expression in Ratl fibroblasts. Quiescent Rat1 fibroblasts were pre-treated for $30 \mathrm{~min}$ with vehicle alone (open symbols) or with $50 \mu \mathrm{M}$ PD98059 (closed symbols). The cells were then stimulated with $10 \%$ calf serum $(\triangle, \boldsymbol{\nabla})$ or $1 \%$ calf serum $(O, \boldsymbol{\bullet})$ for the indicated period of times. (a) Enzymatic activity of ERK1. Cell lysates were prepared and subjected to immunoprecipitation with a specific ERK1 antiserum. The phosphotransferase activity of ERK1 was assayed directly using MBP as substrate. The enzymatic activities are expressed as pmoles of phosphate incorporated into the substrate per min per $\mathrm{mg}$ of lysate protein. (b) expression of MKP-1 protein analysed by immunoblotting as described in Figure 1. (c) Expression of $M K P-1$ mRNA analysed by Northern hybridization using a ${ }^{32}$ P-labeled $M K P-1$ cDNA as probe. Rehybridization of the membrane with a GAPDH probe confirmed that similar amounts of RNA were loaded in each lane (data not shown) 
interfering with the upstream activation of the MAP kinase kinases MEK1/MEK2 (Dudley et al., 1995; Alessi et al., 1995; Servant et al., 1996). Incubation of Ratl cells with $50 \mu \mathrm{M}$ PD98059 resulted in little inhibition of MKP-1 protein expression in response to $10 \%$ serum (Figure $8 \mathrm{~b}$ ). However, in the presence of high serum concentration, PD98059 was found to only partially block the activation of ERK1 (Figure 8a). Other workers also reported that PD98059 does not inhibit the activation of ERK1/ERK2 completely when cells are stimulated with high concentrations of agonists (Alessi et al., 1995; Flynn and Proud, 1996). Thus, to further evaluate the involvement of ERK1/ERK2 in the regulation of MKP-1 expression, we tested the effect of PD98059 at sub-optimal serum concentration. When Rat1 cells were stimulated with 1\% serum, PD98059 completely suppressed the activation of ERK1 and, under these conditions, partially inhibited the expression of MKP-1 protein (Figure $8 \mathrm{a}$ and b). However, PD98059 had no significant effect on the accumulation of $M K P-1$ mRNA in these cells (Figure 8c). It is important to underline that PD98059 inhibits growth factor-induced protein synthesis at this concentration (Servant et al., 1996), which may explain the decrease in MKP-1 protein. These results argue that activation of MAP kinases is not an absolute requirement for the induction of $M K P-1$ gene transcription by extracellular stimuli.

\section{Discussion}

$M K P-1$ is an immediate-early gene that is rapidly and transiently induced in response to growth factors and cellular stress. The $M K P-1$ gene encodes a VH1-like dual-specificity phosphatase which exhibits catalytic activity towards MAP kinases in vitro. Little is known about the mechanisms that regulate $M K P-1$ gene expression and about the physiological roles of the enzyme. In this study, we show that in fibroblast cells: (1) $\mathrm{Ca}^{2+}$ is both necessary and sufficient for the induction of $M K P-1$ gene expression; and (2) activation of MAP kinases is not an absolute requirement for induction of the $M K P-1$ gene.

Pharmacological experiments with various signalling inhibitors have revealed that chelation of intracellular $\mathrm{Ca}^{2+}$ with BAPTA completely blocks serum-induced MKP-1 expression in a time- and dose-dependent manner. The inhibitory effect of BAPTA was observed at the level of the protein and the mRNA, thereby suggesting that $\mathrm{Ca}^{2+}$ may be required for transcriptional activation of the $M K P-1$ gene. The following observations illustrate the central role of $\mathrm{Ca}^{2+}$ in the regulation of MKP-1 expression. First, $\mathrm{Ca}^{2+}$ chelation blocks the induction of MKP-1 expression in response to all stimuli tested, including $G$ protein-coupled receptor agonists, receptor tyrosine kinase agonists, or physical stress. Second, the $\mathrm{Ca}^{2+}$ requirement of MKP-1 expression is not restricted to fibroblasts but is also observed in other cell types such as vascular SMC. Third, increasing the intracellular concentration of $\mathrm{Ca}^{2+}$ with the ionophore A23187 is sufficient to induce the expression of MKP-1 mRNA and protein. Similar observations were made in the lymphoma cell line 2PK-3 (Mittelstadt and Defranco, 1993) and in rat aortic SMC (Duff et al., 1993) using the calcium ionophore ionomycin. It is noteworthy that the stimulatory effect of A23187 on MKP-1 expression is slightly delayed in comparison to serum and of lower magnitude. This suggests that an additional $\mathrm{Ca}^{2+}$ independent pathway(s) is recruited by serum to stimulate full transcription of the $M K P-1$ gene.

The mechanism by which $\mathrm{Ca}^{2+}$ regulates $M K P-1$ gene expression is currently unknown. $\mathrm{Ca}^{2+}$ is a widespread second messenger which participates to a host of cellular changes including gene expression (Clapham, 1995). Elevation of intracellular $\mathrm{Ca}^{2+}$ levels has been shown to activate transcription of a number of eukaryotic genes through phosphorylation of transcription factors that bind to the CRE (cAMPresponsive element) (Sheng et al., 1990; 1991; Dash et al., 1991; Liu et al., 1993). This effect of $\mathrm{Ca}^{2+}$ may be mediated by the multifunctional $\mathrm{Ca}^{2+} /$ calmodulindependent protein kinases (Schulman, 1993) which can phosphorylate and activate different members of the CRE-binding protein (CREB)/activating transcription factor (ATF) family, such as CREB, CREM $\tau$ and ATF-1 (Dash et al., 1991; Sheng et al., 1991; Shimomura et al., 1996; de Groot et al., 1993; Sun et al., 1994c). In T lymphocytes, the activation of nuclear factor of activated $\mathrm{T}$ cells (NF-AT) is quantitatively correlated with the intracellular concentration of $\mathrm{Ca}^{2+}$ (Negulescu et al., 1994). The influx of $\mathrm{Ca}^{2+}$ through voltage-sensitive $\mathrm{Ca}^{2+}$ channels also stimulates serum response factor (SRF)-dependent transcription in the pheochromocytoma cell line PC12 (Miranti et al., 1995). Sequencing of the $5^{\prime}$ flanking region of the mouse $M K P-1$ gene revealed the presence of several consensus sequences that include one CRE, two SP1 sites, two $\mathrm{CTF} / \mathrm{NF} 1-$ like sites, and one E-box motif (Noguchi et al., 1993). The human $M K P-1$ gene is also flanked by two CREs (Kwak et al., 1994). In contrast to other immediate-early genes, no serum response element (SRE) has been found. Although the role of these different elements in the transcriptional activation of $M K P-1$ remains to be determined, it is tempting to speculate that the $\mathrm{CRE}$ may mediate the response to $\mathrm{Ca}^{2+}$. In support of this hypothesis, cAMP was found to strongly induce $M K P-1$ mRNA expression in NIH3T3 cells (Noguchi et al., 1993).

The expression of $M K P-1 \mathrm{mRNA}$ is induced by a range of stimuli that also trigger the activation of MAP kinase pathways in mammalian cells. This suggests that MAP kinase activity may be required for $M K P-1$ transcription, thereby providing a feedback loop to inactivate the signalling pathway (Sun and Tonks, 1994a). In fission yeast, activation of the stressactivated MAP kinase Spc1/Sty1 leads to expression of the pyp2 $2^{+}$gene in a manner dependent upon the Atf1 transcription factor (Millar et al., 1995; Shiozaki and Russel, 1996; Wilkinson et al., 1996). The pyp2 $2^{+}$ gene encodes a tyrosine-specific protein phosphatase which dephosphorylates Spc1/Styl in a feedback inhibition loop. Recently, Grumont et al. (1996) have provided evidence suggesting that ERK2 activation is necessary for phorbol esters and $\mathrm{v}$-Ras-dependent transcription of the $P a c-1$ gene in T lymphocytes. In another study, Bokemeyer et al. (1996) reported that expression of an active mutant of MEK kinase-1 in NIH3T3 cells leads to $M K P-1$ gene induction. However, the findings reported in this study together with observations by other groups suggest that MAP 
kinases are not obligatory components of the signalling pathways that regulate $M K P-1$ gene expression. We have found that exposure of rat fibroblasts to the $\mathrm{Ca}^{2+}$ ionophore A23187 induces $M K P-1$ mRNA expression without significantly activating the JNK and p38 MAP kinase pathways. Moreover, treatment with SB203580, a highly selective inhibitor of p38 MAP kinase (Lee et al., 1994), had little or no effect on the induction of MKP-1 expression by serum (data not shown). We also show that incubation of rat fibroblasts with a concentration of PD98059 that blocks ERK1/ERK2 activation does not interfere with serum-stimulated MKP-1 mRNA expression. The observation that PD98059 partly inhibits MKP-1 protein expression most likely reflects the inhibitory effect of the compound on protein synthesis. Indeed, we have recently demonstrated that addition of PD98059 (Servant et al., 1996) or expression of a dominantnegative mutant of ERK1 (Gopalbhai K and Meloche $\mathrm{S}$, unpublished data) block growth factor-stimulated protein synthesis in target cells.

Other studies also reported a lack of correlation between the activation of MAP kinases and the induction of $M K P-1$ gene transcription in various cell types. For example, treatment of B lymphocytes (Mittelstadt and DeFranco, 1993) or NIH3T3 cells (Bokemeyer et al., 1996) with phorbol esters was found to stimulate the phosphorylation of ERK isoforms without inducing $M K P-1$ gene expression. Also, expression of a constitutively-active MEK1 mutant failed to increase $M K P-1$ mRNA expression in NIH3T3 cells, whereas a dominant-negative form of the kinase potentiated serum or anisomycin-induced MKP-1 gene expression (Bokemeyer et al., 1996). In HeLa cells, treatment with the genotoxic agent methyl methanesulfonate strongly induced $M K P-1$ mRNA expression but had little effect on ERK1/ERK2 activity (Liu et al., 1995). In murine macrophages expressing an oncogenic $\Delta \mathrm{Raf}-1$ : estrogen receptor ( $\triangle \mathrm{Raf}-1-\mathrm{ER})$ fusion protein, the $M K P-1$ gene was shown to be induced in response to lipopolysaccharide stimulation but not in response to activation of $\Delta \mathrm{Raf}-$ 1-ER with estradiol, despite the rapid and prolonged activation of ERK1/ERK2 (Hambleton et al., 1995). Finally, treatment of Rat1 cells with the PKC inhibitor Ro-31-8220 was recently reported to activate the JNK pathway, but to inhibit growth factor-stimulated expression of MKP-1 (Beltman et al., 1996). Taken together, these observations indicate that activation of signalling pathways other than the three known MAP kinase modules is required for full transcription of the $M K P$-1 gene.

\section{Materials and methods}

\section{Materials and antibodies}

Tissue culture reagents and epidermal growth factor were purchased from Life Technologies. Thrombin, 2-aminopurine, bovine myelin basic protein (MBP), anisomycin, and protease inhibitors were from Sigma. Angiotensin II was obtained from Hukabel Scientific. Phorbol 12-myristate 13acetate (PMA), K-252a, and genistein were from LC Services. BAPTA (1,2-bis(o-aminophenoxy) ethane$\mathrm{N}, \mathrm{N}, \mathrm{N}^{\prime}, \mathrm{N}$-tetraacetic acid tetra (acetoxymethyl) ester) and A23187 were from Calbiochem. Go6976 and herbimycin A were from Biomol. CGP41251 and the biologically inactive analogue CGP42700 were gifts from Ciba-Geigy. $\left[\gamma-{ }^{32} \mathrm{P}\right] \mathrm{ATP}$ was from Amersham Corp. PD98059 was a gift from Parke-Davis. The bacterial expression plasmids encoding GST-ATF2 and GST-c-Jun were kindly provided by Dr Roger Davis (University of Massachussets) and Dr Jim Woodgett (Ontario Cancer Institute), respectively. The recombinant fusion proteins were expressed in E. coli and purified as described (Guan and Dixon, 1991b).

The anti-MKP-1 polyclonal antibody was obtained from Santa-Cruz Biotechnology. Antiserum SM1 has been described and specifically immumoprecipitates ERK1 isoform (Meloche, 1995). The polyclonal antibodies to JNK2 and p38 were generously provided by Dr Jacques Landry (Université Laval).

\section{Cell culture}

Rat1 cells were cultured in minimum essential medium (MEM) supplemented with $10 \%$ calf serum, $2 \mathrm{~mm}$ glutamine and antibiotics (Meloche, 1995). They were made quiescent by incubation in serum-free Dulbecco's modified Eagle's medium (DMEM)/F12 (1:1) containing $15 \mathrm{~mm}$ HEPES (pH 7.4) and $1 \mathrm{mg} / \mathrm{ml} \mathrm{BSA}$ for $24 \mathrm{~h}$. Rat aortic SMC were cultured and synchronized as described previously (Giasson and Meloche, 1995).

\section{Immunoblot analysis of $M K P-1$}

Following stimulation with the indicated agents, the cells were washed twice with ice-cold phosphate-buffered saline (PBS) and lysed in Triton X-100 lysis buffer $(50 \mathrm{~mm}$ Tris$\mathrm{HCl}, \mathrm{pH} 7.4,100 \mathrm{~mm} \mathrm{NaCl}, 50 \mathrm{~mm}$ sodium fluoride, $5 \mathrm{~mm}$ EDTA, $40 \mathrm{~mm} \beta$-glycerophosphate, $1 \mathrm{~mm}$ sodium orthovanadate, $10^{-4} \mathrm{M}$ phenylmethylsulfonyl fluoride, $10^{-6} \mathrm{M}$ leupeptin, $10^{-6} \mathrm{M}$ pepstatin A, $1 \%$ Triton X-100). After $25 \mathrm{~min}$ at $4{ }^{\circ} \mathrm{C}$, the lysates were clarified by centrifugation at $13000 \times g$ for $10 \mathrm{~min}$ at $4^{\circ} \mathrm{C}$. Equal amounts of lysate proteins $(100 \mu \mathrm{g})$ were subjected to SDS-gel electrophoresis on $10 \%$ acrylamide gels and transferred to Hybond-C nitrocellulose membranes (Amersham) in $25 \mathrm{~mm}$ Tris, $192 \mathrm{~mm}$ glycine. Membranes were blocked in Tris-buffered saline (TBS) containing 5\% non-fat dry milk and $0.05 \%$ Tween-20 for $45 \mathrm{~min}$ at $37^{\circ} \mathrm{C}$ prior to incubation for $60 \mathrm{~min}$ at room temperature with anti-MKP-1 antibody $(1 \mu \mathrm{g} / \mathrm{ml})$ in blocking solution. The membranes were washed three times in TBS containing $0.05 \%$ Tween-20 (TBST) prior to incubation for $30 \mathrm{~min}$ at room temperature with horseradish peroxidase-conjugated goat antirabbit $\mathrm{IgG}$ diluted 1:10000 in blocking solution. After washing as above, the immunoreactive bands were visualized by enhanced chemiluminescence (Amersham).

\section{Protein kinase assays}

The enzymatic activity of JNK2, ERK1 and p38 was measured by specific immune complex kinase assays using GST-c-Jun, MBP and GST-ATF2 as substrates, respectively. The assay of ERK1/ERK2 has been described previously (Meloche, 1995; Giasson and Meloche, 1995). For JNK2 assays, cell lysates were prepared as described above and $500 \mu \mathrm{g}$ of proteins were incubated for $2 \mathrm{~h}$ at $4^{\circ} \mathrm{C}$ with $2 \mu \mathrm{l}$ of anti-JNK2 antibody preadsorbed to protein ASepharose (Pharmacia) beads. The immune complexes were washed three times with lysis buffer and once with JNK assay buffer (20 mM HEPES, pH 7.4, $20 \mathrm{mM} \mathrm{MgCl}_{2}, 2 \mathrm{mM}$ dithiothreitol (DTT), $20 \mathrm{mM} \beta$-glycerophosphate, $100 \mu \mathrm{M}$ sodium orthovanadate). The beads were then resuspended in $40 \mu \mathrm{l}$ of JNK assay buffer containing $1 \mu \mathrm{g}$ GST-c-Jun, $50 \mu \mathrm{M}$ ATP and $5 \mu \mathrm{Ci}\left[\gamma-{ }^{32} \mathrm{P}\right] \mathrm{ATP}$. The reaction was initiated with ATP, incubated at $30^{\circ} \mathrm{C}$ for $15 \mathrm{~min}$, and stopped by addition of $2 \times$ Laemmli's sample buffer. The 
samples were analysed by SDS-gel electrophoresis and autoradiography.

For p38 assays, $150 \mu \mathrm{g}$ of lysate proteins were incubated for $2 \mathrm{~h}$ at $4{ }^{\circ} \mathrm{C}$ with $5 \mu \mathrm{l}$ of anti-p38 antibody coupled to protein A-Sepharose. The immune complexes were washed as above. The beads were then resuspended in $20 \mu \mathrm{l}$ of $\mathrm{p} 38$ kinase assay buffer (25 mM HEPES, pH 7.4, $25 \mathrm{mM} \mathrm{MgCl}_{2}$, $2 \mathrm{mM}$ DTT, $25 \mathrm{mM} \quad \beta$-glycerophosphate, $100 \mu \mathrm{M}$ sodium orthovanadate) containing $1 \mu \mathrm{g}$ GST-ATF2, $50 \mu \mathrm{M}$ ATP, and $3 \mu \mathrm{Ci}\left[\gamma-{ }^{32} \mathrm{P}\right] \mathrm{ATP}$. The enzymatic reaction was carried out at $30^{\circ} \mathrm{C}$ for $30 \mathrm{~min}$ and analysed as described for JNK2.

\section{Northern blot analysis}

Total RNA was extracted by a modified version of the guanidinium thyocyanate procedure as described (Chomczinzki and Sacchi, 1987; Chomczynski, 1993). Equal amounts of total RNA $(15-25 \mu \mathrm{g})$ were denatured by heating for $15 \mathrm{~min}$ at $65^{\circ} \mathrm{C}$ in $2.2 \mathrm{M}$ formaldehyde and $50 \%$ formamide and resolved by electrophoresis in a $1 \%$ agarose gel containing $1.8 \%$ formaldehyde. The RNA were transferred to Hybond-N membranes (Amersham), fixed, and hybridized with ${ }^{32} \mathrm{P}-$ labeled probes. Hybridization was carried out in hybridization medium $[5 \times \mathrm{SSC}$ $(1 \times \mathrm{SSC}=150 \mathrm{mM} \mathrm{NaCl}, 15 \mathrm{mM}$ sodium citrate $), 0.1 \%$ SDS, $5 \times$ Denhardt's solution $(1 \times$ Denhardt's $=0.02 \%$ Ficoll $400,0.02 \%$ polyvinyl pyrrolidone and $0.02 \%$ bovine serum albumin), $50 \%$ formamide, and $100 \mu \mathrm{g} / \mathrm{ml}$ herring sperm DNA] containing the labeled probe (1$2 \times 10^{6}$ c.p.m. $/ \mathrm{ml}$ ) for $16 \mathrm{~h}$ at $42^{\circ} \mathrm{C}$. The membranes were

\section{References}

Akiyama T, Ishida J, Nakagawa S, Ogawara H, Watanabe S-i, Itoh N, Shibuya M and Fukami Y. (1987). J. Biol. Chem., 262, 5592-5595.

Alessi DR, Smythe C and Keyse SM. (1993). Oncogene, 8, 2015-2020.

Alessi DR, Cuenda A, Cohen P, Dudley DT and Saltiel AR. (1995). J. Biol. Chem., 270, $27489-27494$.

Beltman J, McCormick F and Cook SJ. (1996). J. Biol. Chem., 271, 27018-27024.

Bokemeyer D, Sorokin A, Yan M, Ahn NG, Templeton DJ and Dunn MJ. (1996). J. Biol. Chem., 271, 639-642.

Brondello JM, McKenzie FR, Sun H, Tonks NK and Pouysségur J. (1995). Oncogene, 10, $1895-1904$.

Cano E and Mahadevan LC. (1995). Trends Biochem. Sci., 20, $117-122$

Charles CH, Abler AS and Lau LF. (1992). Oncogene, 7, $187-190$.

Charles CH, Sun H, Lau LF and Tonks NK. (1993). Proc. Natl. Acad. Sci. USA, 90, 5292-5296.

Chomczinski P and Sacchi N. (1987). Anal. Biochem., 162, $156-159$.

Chomczynski P. (1993). BioTechniques, 15, 532-537.

Chu Y, Solski PA, Khosravi-Far R, Der CJ and Kelly K. (1996). J. Biol. Chem., 271, 6497-6501.

Clapham DE. (1995). Cell, 80, 259-268.

Cobb MH, Boulton TG and Robbins DJ. (1991). Cell Regul., 2, $965-978$.

Cobb MH and Goldsmith EJ. (1995). J. Biol. Chem., 270, $14843-14846$

Dash PK, Karl KA, Colicos MA, Prywes R and Kandel ER. (1991). Proc. Natl. Acad. Sci. USA, 88, $5061-5065$.

Davis RJ. (1994). Trends Biochem. Sci., 19, 470-473.

de Groot RP, den Hertog J, Vandenheede JR, Goris J and Sassone-Corsi P. (1993). EMBO J., 12, 3903-3911.

De Jonge PC, Wieringa T, Van Putten JP, Krans HM and Van Dam K. (1983). Biochim. Biophys. Acta, 722, 219 225. washed twice at $25^{\circ} \mathrm{C}$ for $15 \mathrm{~min}$ in $2 \times \mathrm{SSC}, 0.1 \% \mathrm{SDS}$ and twice at $60^{\circ} \mathrm{C}$ for $30 \mathrm{~min}$ in $0.5 \times \mathrm{SSC}, 0.1 \% \mathrm{SDS}$. The extent of hybridization was analysed with a phosphorimager apparatus (Molecular Dynamics). The results were normalized to glyceraldehyde-3-phosphate dehydrogenase (GAPDH) mRNA.

The probes used were: a $1.2 \mathrm{~kb}$ PvuII-NotI fragment of human $M K P-1$ cDNA (provided by Dr Stephen Keyse, ICRF), and a $1.2 \mathrm{~kb}$ XbaI-PstI fragment of rat GAPDH cDNA. All the probes were labeled by random priming.

\section{Other methods}

Protein concentrations were measured using the BCA protein assay kit (Pierce) with bovine serum albumin as standard.

\section{Acknowledgements}

We thank Drs A Suter, A Saltiel, RJ Davis, J Woodgett, J Landry and SM Keyse for reagents. We also thank E Pérès for preparation of the figures and I Rémillard for secretarial assistance. This work was supported by a grant from the National Cancer Institute of Canada. J-C Scimeca is recipient of a fellowship from the Association pour la Recherche contre le Cancer and invited scientist of the Fonds de la recherche en santé du Québec, MJ Servant is recipient of a Heart and Stroke Foundation of Canada studentship and S Meloche is a Scholar of the Medical Research Council of Canada.

Dudley DT, Pang L, Decker SJ, Bridges AJ and Saltiel AR. (1995). Proc. Natl. Acad. Sci. USA, 92, 7686-7689.

Duff JL, Marrero MB, Paxton WG, Charles CH, Lau LF, Bernstein KE and Berk BC. (1993). J. Biol. Chem., 268, 26037-26040.

Flynn A and Proud CG. (1996). FEBS Lett., 389, 162-166.

Force T, Pombo CM, Avruch JA, Bonventre JV and Kyriakis JM. (1996). Circ. Res., 78, 947-953.

Fukuda M, Gotoh Y, Tachibana T, Dell K, Hattori S, Yoneda Y and Nishida E. (1995). Oncogene, 11, 239-244.

Giasson E and Meloche S. (1995). J. Biol. Chem., 270, $5225-$ 5231.

Grumont RJ, Rasko JEJ, Strasser A and Gerondakis S. (1996). Mol. Cell. Biol., 16, $2913-2921$.

Guan K, Broyles SS and Dixon JE. (1991). Nature, 350, $359-362$.

Guan KL and Dixon JE. (1991b). Anal. Biochem., 192, $262-$ 267.

Guan KL and Butch E. (1995). J. Biol. Chem., 270, $7197-$ 7203.

Hambleton J, McMahon M and DeFranco AL. (1995). $J$. Exp. Med., 182, $147-154$.

Han J, Lee JD, Bibbs L and Ulevitch RJ. (1994). Science, 265, $808-811$

Ishibashi T, Bottaro DP, Chan A, Miki T and Aaronson SA. (1992). Proc. Natl. Acad. Sci. USA, 89, 12170-12174.

Ishibashi T, Bottaro DP, Michieli P, Kelley CA and Aaronson SA. (1994). J. Biol. Chem., 269, 29897-29902.

Kase H, Iwahashi K, Nakanishi S, Matsuda Y, Yamada K, Takahashi M, Murakata C, Sato A and Kaneko M. (1987). Biochem. Biophys. Res. Commun., 142, 436-440.

Keyse SM and Emslie EA. (1992). Nature, 359, 644-647.

Keyse SM. (1995). Biochim. Biophys. Acta, 1265, 152-160.

King AG, Ozanne BW, Smythe C and Ashworth A. (1995). Oncogene, 11, 2553-2563.

Kwak SP, Hakes DJ, Martell KJ and Dixon JE. (1994). $J$. Biol. Chem., 269, 3596-3604. 
Kwak SP and Dixon JE. (1995). J. Biol. Chem., 270, $1156-$ 1160.

Kyriakis JM, Banerjee P, Nikolakaki E, Dai T, Rubie EA, Ahmad MR, Avruch J and Woodgett JR. (1994). Nature, 369, $156-160$.

L'Allemain G. (1994). Prog. Growth Factor Res., 5, 291 - 334.

Lee JC, Laydon JT, McDonnell PC, Gallagher TF, Kumar S, Green D, NcNulty D, Blumenthal MJ, Heys JR, Landvatter SW, Strickler JE, McLaughlin MM, Siemens IR, Fisher SM, Livi GP, White JR, Adams JR and Young PR. (1994). Nature, 372, $739-746$.

Liu F, Thompson MA, Wagner S, Greenberg ME and Green MR. (1993). J. Biol. Chem., 268, 6714-6720.

Liu Y, Gorospe M, Yang C and Holbrook NJ. (1995). J. Biol. Chem., 270, 8377-8380.

Mahadevan LC, Wills AJ, Hirst EA, Rathjen PD and Heath JK. (1990). Oncogene, 5, 327-335.

Marte BM, Meyer T, Stabel S, Standke GJR, Jaken S, Fabbro D and Hynes NE. (1994). Cell Growth Differ., 5, $239-247$.

Martell KJ, Seasholtz AF, Kwak SP, Clemens KK and Dixon JE. (1995). J. Neurochem., 65, 1823-1833.

Martiny-Baron G, Kazanietz MG, Mischak H, Blumberg PM, Kochs G, Hug H, Marmé D and Schächtele C. (1993). J. Biol. Chem., 268, 9194-9197.

Meloche S. (1995). J. Cell. Physiol., 163, 577- 588.

Meyer T, Regenass U, Fabbro D, Alteri E, Rösel J, Müller M, Caravatti G and Matter A. (1989). Int. J. Cancer, 43, $851-856$

Millar JBA, Buck V and Wilkinson MG. (1995). Genes Dev., 9, 2117-2130.

Miranti CK, Ginty DD, Huang G, Chatila T and Greenberg ME. (1995). Mol. Cell. Biol., 15, 3672-3684.

Misra-Press A, Rim CS, Yao H, Roberson MS and Stork PJS. (1995). J. Biol. Chem., 270, $14587-14596$.

Mittelstadt PR and DeFranco AL. (1993). J. Immunol., 150, $4822-4832$.

Mourey RJ, Vega QC, Campbell JS, Wenderoth MP, Hauschka SD, Krebs EG and Dixon JE. (1996). J. Biol. Chem., 271, 3795-3802.

Muda M, Boschert U, Dickinson R, Martinou J-C, Martinou I, Camps M, Schlegel W and Arkinstall S. (1996). J. Biol. Chem., 271, 4319-4326.
Negulescu PA, Shastri N and Cahalan MD. (1994). Proc. Natl. Acad. Sci. USA, 91, 2873-2877.

Noguchi T, Metz R, Chen L, Mattéi MG, Carrasco D and Bravo R. (1993). Mol. Cell. Biol., 13, 5195-5205.

Raingeaud J, Gupta S, Rogers JS, Dickens M, Han J, Ulevitch RJ and Davis RJ. (1995). J. Biol. Chem., 270, $7420-7426$.

Rohan PJ, Davis P, Moskaluk CA, Kearns M, Krutzsch H, Siebenlist U and Kelly K. (1993). Science, 259, $1763-$ 1766.

Rouse J, Cohen P, Trigon S, Morange M, Alonso-Lamazares A, Zamanillo D, Hunt T and Nebreda AR. (1994). Cell, 78, $1027-1037$.

Schulman H. (1993). Curr. Opin. Cell. Biol., 5, 247-253.

Servant MJ, Giasson E and Meloche S. (1996). J. Biol. Chem., 271, 16047-16052.

Sheng M, McFadden G and Greenberg ME. (1990). Neuron, 4, $571-582$.

Sheng M, Thompson MA and Greenberg ME. (1991). Science, 252, $1427-1430$.

Shimomura A, Ogawa Y, Kitani T, Fujisawa $\mathrm{H}$ and Hagiwara M. (1996). J. Biol. Chem., 271, 17957-17960.

Shiozaki K and Russel P. (1996). Genes Dev., 10, 2276-2288.

Sun H, Charles CH, Lau LF and Tonks NK. (1993). Cell, 75, $487-493$.

Sun H and Tonks NK. (1994a). Trends Biochem. Sci., 480485.

Sun H, Tonks NK and Bar-Sagi D. (1994b). Science, 266, $285-288$

Sun, P Enslen H, Myung PS and Maurer RA. (1994c). Genes Dev., 8, 2527-2539.

Uehara Y, Fukazawa H, Murakami Y and Mizuno S. (1989). Biochem. Biophys. Res. Commun., 163, 803-809.

Ward Y, Gupta S, Jensen P, Wartmann M, Davis RJ and Kelly K. (1994). Nature, 367, 651-654.

Waskiewicz AJ and Cooper JA. (1995). Curr. Opin. Cell. Biol., 7, $798-805$.

Wilkinson MG, Samuels M, Takeda T, Toone WM, Shieh JC, Toda T, Millar JBA and Jones N. (1996). Genes Dev., 10, $2289-2301$.

Zheng C-F and Guan K-L. (1993). J. Biol. Chem., 268 , $16116-16119$ 